\title{
我國電登事業の發薘に就で
}

\author{
名譽會員工學博士中原 岩 三 郎
}

\section{Development of the Electric Lighting Business in Japan.}

By Dr. I. Nakahara Honourable Member.

\begin{abstract}
目次
1. 緒 言

2. エヂソン氏の發明前後に於けろ電球

3. 電燈供給事業

4. 電球及電燈用機械器具の製造

5. 結 論

\section{内 容 梗 概}

本文は電燈五十年記念會, 電氣照明兩學會主催講 演會 (10月 3 日) の講演にこて, 上記目次の如くエ ヂンン氏の電球發明當時より現在の瓦斯入電球に至 万迄の電球の進歩墢達より述一，我國に於け万電燈 供給事業が明治20年僅かに 130 燈か以て開始さられ

てより今日に及べろ有樣, 電球及電燈用機械器具の 製造業の發達の有樣, 及ひ電燈供給事業は更に合理 的に又積極的に淮み，照明の應用施して益々有效に 利用せこめ以て斯業の伸展に盡すべきものであるこ 結論せるものである。
\end{abstract}

\section{SYNOPSIS}

The present paper comprises the following articles :

(1) Preface, (2) Electric lamps before and after the time when Edison first invented his incandescent electric lamp, (3) Electric lighting enterprizes in Japan, (4) Manufacturing of Electric lamps and of various machinery and apparatus for lighting purposes and (5) Conclusion.

The author describes the progress of electric lamps, considering the various steps taken in its development since that time of Edison's invention up to the present time when the newest type of gas-filled tungsten-filament incandescent electric lamps is obtainable.

He then takes up the matters of electric lighting enterprizes in this country: under this heading, he explains how remarkably our undertakings in this direction have been achieved, pointing out a fact that when we first started it in 1887, the total number of lamps installed was 130; he next gives some comments on the development of manufacturing various machinery and apparatus for lighting purposes.

In conclusion, he states that the electric light supplying business should further be rationalized and positively planned in the future, so that electric lighting would more extensively be utilized for illumination, thus enabling to assist our country economically. He wishes to extend hearty appreciation for what Mr. Edison has done to us human beings, and hopes at the same time that a hundred Edison's will appear in this country.

* This paper was read before a Joint Meeting of the Institute of Electrical Engineers of Japan and Illuminating Engineering Society, which was held on October 3 rd., 1929, as a part of the Program of Light's Golden Jubilee. 


\section{1. 緒言}

今年の10月は，エデソン氏が現在世界を通じて一般照明用として最も廣く探用せられてるる所の 白熱電球の最初の䆩用的電球を發明創造し，上て吾人生活上に大なる福䄳をるたらしめたと共に， 電登事業をして今日に於ける隆盛の基を作られた時より，丁度霂50年に相當するに依り之を記念す へく國際的に電燈50年記念會か;開催せらるつことになりました. 我國に於てを學會協會等協同の下 に記念會が創立せ弓れ各種の記念計劃か現に實行せられておらまして, 我電氣學會及照明學會に於 ても兩學會聯合主催にて本講演會が本日開催せられた次第にて, 私も其の講演者の一人として此の 席に立つ事を光策とするすのであります.

エヂソン氏の白熱電球發明當時の前後に於ては氏の外に之か;研究發明に從事して居た各國の學者 研究家は色々あつたか，其中に於て氏の發明が前述の如く電登事業發澾の基をなしたと云ふ事は單 に氏の發明せる電球が賽用的のものであつたと云ふ以外に，氏の發明力は電球以外の配電方式，機 械器具の改良發明に及び以て其基礎を作られた努力貢獻か與かつて大なるものであつたと信するも のであります. 即ち單なる 1 個の電球でも之を實用的に點火する迄には其周圍の各種物件に對して 賽に大なる䂰究と苦心が拂はれた事筫を認めなければならないと思ふと共に，此無名の青年發明家 をして其名をなさしめた鿵れたる後援者に對しても考へ度いと思ふ. 而して一國の產業の盛㐮は賁 に發明と不断の研究に待つこと大なるものであるから諸君と共に一㡺の努力を此點に盡し度いと考 へろ次第であります. 而して私の演題は「我國電燈事業の發達に就て」となつて居りますか; 總論 的にェヂソン氏發明前後の事を一言附け加へました。

\section{2. エヂソン氏前後に於ける電球}

電氣なる言葉は約 2500 年前希臘に於て秘に使用せられた樣であるか，1800 年頃迄は其人工的現

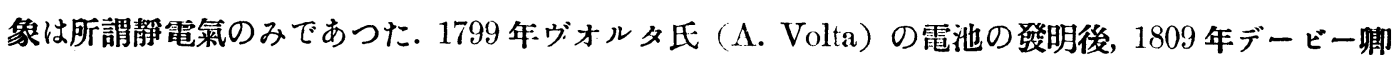
（Sir H. Davy）が木炭に電氣を通じ電弧の實驗を發表してから識者の間に電燈なるるのか注意せ られて來た．而して 1831 年ファラデー氏 (M. Farady) の誘導電氣の發見に基ける電氣機珹製造 の發達に伴ひ弧光燈が發達して 1878 年ブラシュ氏 (C. F. Brush) に依り簀用的弧光登が完成せ られ，次で 1883-1884 年, トムソン氏（E. Thomson）に依り 25 鄧用弧光燈發電機の製作と共 に所謂トムソン，ハウストン式 10 アンペア 40-50 ヴオルト直列式回路に於て完全に街燈が弧光 登を以て實用に供せられた. 而して弧光燈は其後主として屋外に於て發達し, 次述の白熱電燈は屋 內燈として發達して來たのであります。

白熱電登の發澾は 1820 年ド・ラ・ルー氏 (De le Rue) の發明後各種の發明が色々の研究者に依 ๖10數種發表せられたが何れも實用的のものにはならなかつた. 1878 年 12月にスワン卿 (Sir J. Swan）が所謂スワン炭素電球を發明發表せられた．其見本現品は現に英國ロンドン市の科䀜博物 館 (National Science Museum) にある. 次で 1879 年 10 月 21 日エヂソン氏が高抵抗樴條の炭 素電球の最初のものを發明完成致しました。. 白熱作用の原理に依り作られた電球は上記の如く各種 
多數あつたが，110 ヴオルト級の併列式回路に於て實用的に點登せられたものは氏の電球が最初で あります．當時の電燈用發電機及配電方式等は凡て弧光燈と共に發達せるものにて定電流直列式の ものであつたが，エヂソン氏は發電機及器具等をも改良發明して定電歷併列式のものを探用した。 エヂソンダイナモ，エヂソン配電方式，エヂソンベース等の名稱は當時に於ける研究の結晶を物語 ろものであります.

エ夭゙ッン氏發明當初の電球は比消費量 1 水本燭當り 7 ワト位, 能率 1.4 ルーメン/ワットで壽

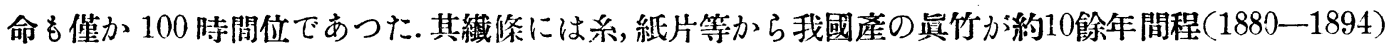
引續き使用せられた．從て此電球の發達と我國との閒には間接ながら 1 種の關係があるを思はしむ ると共に氏が各種の使用材料に對し人を世界各國に派して優秀品を集め研究に從事せられた事を敬

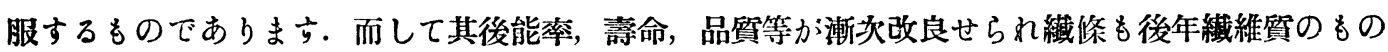
そ代つたのであります，倘氏は後年發達した金屬線電球に就ても當時は周圍の事情か今日の如く發

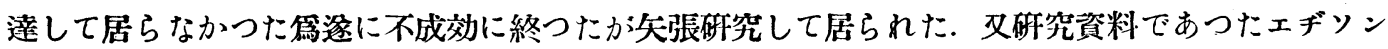
効果の現象も後年異空管，放電々登等の發澾の基をなして居ります。

エヂソン電球の全〈筫用的のものになつたのは 1881 年にて 1 馬力に 8 燈と葐せられた 16 燭光 電球であつて比消費量 6 (能率1.6ルーメン/ワット), 讋命は 900 時間と云ふ一定仕樣の標準品と なつた以後である．其柆年の 1882 年に紐青エヂソン照明會社（紐有エヂソン會社の前身）が創立 せられて紐㕕市中に約 1280 餘短の一般公衆の點燈を開始した。之は米國に於けろ電登の一般供給 の最初であります.

其後炭素電球は漸次進步發達したか１905 年に金屬化炭素電球が出現し 1906 年にはタンタラム 電球 (1ワット當り5ルーメン) が作られ其楚年 1907 年にはユスト，ハナマン (A Just and F. Hanaman）兩氏の發明に依るタングステン電球（ 8 ルーメン/ワット）の州現となり電球能率に 大變化を興へた．次で 1911 年クーリッヂ博士 (W. D. Coolidge) の發明に依る引線タングステン が作られて所謂マッダランブ（10ルーメル/ワット）の出現となり，更に 1913 年にはラングそ ユア博士（I. Langmiur）の發明に倸る瓦斯入電球か沛場に發賣せられて後遂に炭素電球は一般市 場から照明用として段々其影を消してタングステン電球に置換へられた．而して白熱電登は其破學 品筫，壽命及能率（20 ルーメン/ワット）に於て著しき進步發澾を示した. 次で不士の發明に係 ろ內面䶕消電球か出現し品種の單純化と標準化か提唱せられて今日の現狀に到着致したのでありま †.

實に 1879 年出現の炭素電球と今日に於けるタングステン電球とを比較する時は能率に於て絢14 分の 1 即ち同一電力で約 14 倍の光度を出す次第となつて居る. 之か５0年間に致された電球の進步

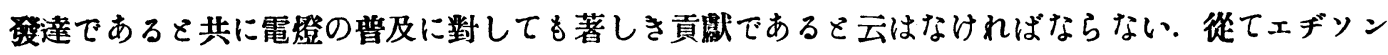
氏の䂭明を感謝すると共に吾人は其後に致された各發明家に對しても亦其の偉大なる奉仕を感謝す 
ろものであります.

\section{3. 電 燈 供 給 事 業}

我國に於けろ最初の電燈點火は矢張胍光燈點火が初めてで 1878 年（明治11年）3月25日（後年電 氣デーと秒人記念日とす) 工部大學に於て行れた. 白熱電球は 1885 年 (明治18年) 大厉紡績會社 及內閣官報局內に行はれたが何れも自家用で小規模のものであつた，一般公䋸用の賽際的のものは 1887年（明治20年）11月東京電燈會社が 東京日本橋附近に小規模の發電設備にて送骊せるが始で あつて，燈數は僅かに 130 餘燈であつたが實に米國の夫に比し僅かに 5 年後に當る. 然し其後我電 燈事業は著しき進步をなしたと云ふす米國今日の現狀と比較する時は照明の普及狀態及電球の使用 數等より見て矢張份數年間の避れがある樣に感ぜらるろのは殘念であります. 東京電燈會社創立當 時の技師長は藤岡博士で私も學校卒業現業に從事致しました。

次で 1888 年 (明治21年) 神戶に, 1889 年（明治22年）に大阪，京都及名古屋に，1890 年（明治 23年）に橫演にと云ふ順次で各都市に電燈供給が開始せられて今日に及びました．今取付燈數買加 等の有樣を約15年後の 1903 年 (明治36年) 分と最近の 10 年即ち 1918 年 (大正 7 年) 及 1927 年 （昭和 2 年）分とを比較して見る時は大凡次の如くなります.

\begin{tabular}{|c|c|c|c|c|}
\hline 年 & $\begin{array}{c}\text { 明 治 } 20 \text { 年 } \\
1887 \text { 年 } \\
\end{array}$ & $\begin{array}{c}\text { 明 } 36 \text { 年 } \\
1903 \text { 年 } \\
\end{array}$ & $\begin{array}{c}\text { 大正 7年 } \\
1918 \text { 年 }\end{array}$ & $\begin{array}{c}\text { 昭和 } 2 \text { 年 } \\
1927 \text { 年 }\end{array}$ \\
\hline 取 付 燈 數 & 130 & 332,322 & $11,900,683$ & $32,322,991$ \\
\hline 右合 & - & 1.00 & 35.90 & 97.30 \\
\hline 電 氣 力 $($ 電燈) $(\mathrm{KW})$ & - & 14,407 & 201,980 & 736,169 \\
\hline 右 割 合 & - & 1.00 & 13.90 & 51.10 \\
\hline 人口 100 人本均燈數 & - & 0.7 & 21.4 & 53.0 \\
\hline 人口 100 人本均電氣力 $(W)$ & - & 31 & 362 & 1,200 \\
\hline 1 燈 本均 燭 光 & - & 12.5 & 13.2 & 18.7 \\
\hline 1 世帶本均需用家數 & - & - & 0.46 & 0.88 \\
\hline 1 需用家本均燈數 & - & - & 2.4 & 3.1 \\
\hline 1 需用家平均電氣力 (W) & - & - & 41.3 & 69.7 \\
\hline
\end{tabular}

配線電壓は最初は發電々壓も迼電々壓も併列式の 100 ヴオルトであつたが大阪電簦會社に於て 1,000 ヴオルト交流發電機が据付けられ其後發電所及水力電氣の隆盛と遠距離電揆の發達と共に送 電々壓は特高電壓となり饋電々壓は高壓が辟通となつたが, 屋內配線電壓は金屬線電球發賣當時に 50 ヴオルト回線が 1 部に探用されたり, 他の電力併用の雼に 200 ヴオルト回線の探用等あつたか， 現在に於ては殆ど一般的に交流式 100 ヴオルト級制に統一せられておる榜である.之は國際的に見 て標準化を荂ることが出來るものである，而して䉓燈とは直接關係無い樣であるけれども周波數が 50 及60兩制の何れにか標準統一せられれば更によいと思ひます.

我國の電短供給制度は定額制に依り出發せる爲に，現在に於ては定額制は全需用家の約 9 割で從 量制は僅に 1 割程で，定額制か;我國供給制の標準制の如き特殊現象を呈して居る.之は電短需用家 
數を世帶數より見る時は 0.88 の普及率に達し殆ど世界一の觀あらしめたのであろが一方配線路よ り見る時は需用家當りの登數は米國では需用家當りアウトレット數約 16 にして推獎は36となつて 居ろのに我國では僅に 3 個であつて能率は低下して居る上に，合理的照明の應用に對しても供給者 に於て常に適當の機關の下に一般公衆を指導して居ると雖も劣不備の點少なからざるうらみがある 樣である．而して時代の芻勢は從量制促進の氣運となり都市を魁として全國に及びつ〉あり，現に 東京市，京都市等に於ては逆に從量需用家は全需用家の絢 8 割內外に達して居ろから一般に更に發 展を見ることであらう．而して現在に於ける我國の照明設備は定額從量何れに拘らず一般に佮研究 すべき點少なくない，工業，商業，家庭，學校，街路等の各方面に對し照明知識の普及と善良な る探光は，交化の發達と共に益々必要なる要件にて之が科學的の發澾は大なる社會奉仕であり又電 燈事業發達の基礎と信するものであつて，本記念會を劃して更に一段の努力が盡されんことを斯業 關係者に希望するものであります。

\section{4. 電球及露燈胃機"械器具製造}

米國に於ては電球製作の發達から電燈會社が創立され我國では電登供給會社設立後電球製作が始 められたので, 1889 年 (明治22年) 8 月東京電燈會社內試驗所に於て藤岡博士, 三宅學士等の苦心 の下に始めて 12 個の炭素電球か自給自足の意味で試作せられたのか我國に於ける實用電球製作の 始であります，翌年 (明治23年) 白熱舍 (東京電氣會社の前身) が創立せられて專門的の電球製作

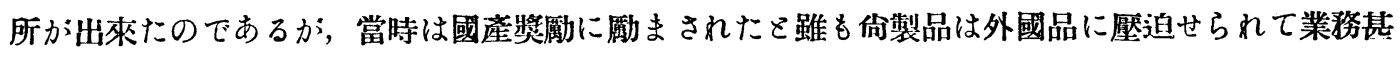
だしく困苦の裡に終始したが藤岡博士, 新莊學士の獻身的の苦心努力の結果, 逐に今日に於ては其 後製造所も種々創立されたものを加へ其全產數量は年額 50,000,000 個以上に昇り，內地に於ては外 國品の跡を絕ちしのみならす多數海外に迄輸出の現狀に到着したのである. 實に我國の電球製作業 は其數量品質及設備に於て何國にも何等遜色無きものに發達したを雖も其理論憵用の原理に對して は，僅かに不破學士の內面龁消の特許等を數ふる以外凡てか外人の考案發明に追隨の有樣にあるは 甚げ残念の次第と思ふ. 特に各國間に於ては現在䒚電球の進步改良に對し種々調查研究か進められ てある樣で, 其の主要々點は現在僅に $20 \%$ 內外にある電球能率の改良にある樣であるが方解決

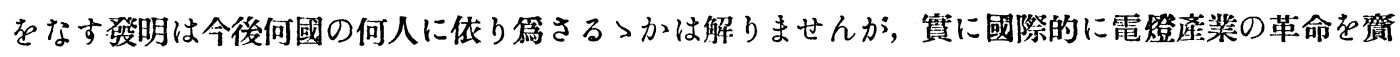
すものとなるのみならす，電登事業界に對しても著しき變化を生ぜしむるものと存じます.

電短用電氣機械器具の製造は 1884 年（明治17年）に藤岡博士指導の下に三吉正一氏が小規模の 工場にて製作開始をなせるか其溚矢である. 最初は直流式エヂソン型發電機の $10 \mathrm{~K} \mathrm{~W}, 15 \mathrm{~K} \mathrm{~W}$ 位のものであつたか高壓發電機探用後之等の製作も創められ，次で電登需用の累進的垻加と相待つ て逘電々壓の上昇と共に發電所變電所設備の發達, 變壓器の進步に伴ひ電機製造工業は著しき發澾。 をとげて現在では電短用諸機械は凡て國產品を以て完備せらるつ樣になりました.

電線類の製作業も電信電話線の製造から發達したのでありますが亦斯業の發達に從ひ需用額の増 
加を以て甚しき發達をなして居ります。

屋內配線設備及照明器具は定額制下に於けるものは他の關係事項が夫れ夫れ著しき發達をなせる にも拘らす創立當時と比較して餘り大なる撜達なく經過して居ります。即ち $\mathrm{P} 1$ シエード, 81 ブ ラケット，296 ノッブ，509 スキッチ等の名稱は會社創立當時の外國商品型錄記載の番號を以て名

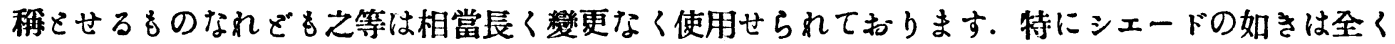
標準品の如く約 40 年間も電球の進步や照明の發達に殆ど無關係の有樣を以て使用せられておりま す. 從て之等の製作業者は只生產數量の堆加のみにて大なる發澾無き有樣であるか從量制度の分は 照明工學の發達に從ひ餘程進步したとは云ふす，之等品程は最も簢單のものでありなから却て優良 品のものに對しては外國の輸入份其の跡を斷たざるのみならず夫等に追隨の餘儀然き嵄な現㹜であ ります. 然し永久的建築物の發達と照明知識の普及と共に斯業も濑次國斑的に發達すべきものと信 するちのであります.

\section{5. 結 論}

我國の電燈事業は電氣及照明の應用と普及に伴ひ其需用は益々增加すへきものに付き今後の發達 は更に大なるものがあらふ。然し料金は供給創始封代には石油燈等に比し恢る高價にて贅澤品の感 があつたが今日に於ては著しく低下し電登は全く日常生活の必要品となつた. 然し作ら一方一層民 篆的に普及せるを以て經營上更に合理的に考虑を要すべき點も多々あるべしと思ふと共に其經營方 法に於ても亦積極的に進むの要あるべく而して照明の應用をして谷々有効に利用せしめ以て國運の 伸展に盡すべきものと信じます。

終に臨で偉人エヂソン氏を敬募し其社會的奉什を感謝すると共に徒に其人的姴素の崇拜に此めす 電氣普及を計るを共に我國に於ても 100 のエヂソン或は更に大なる發明家の出現を期待する道程の 第一步とならしむる樣, 此際催さるつ各種の記念計劃を有意義のものと致し度と熱望するものであ ります. 以上 